\title{
FLEXICURITY AND OBSTACLES IN FRONT: A STUDY FOR THE TOURISM SECTOR IN TURKEY
}

\author{
Michalis TOANOGLOU* \\ Woosong University, SIHOM Department,171 Dongdaejeon-ro, \\ Dong-gu 34606 Daejeon, South Korea, mtoanoglou@sis.ac.kr
}

\begin{abstract}
Citation: Toanoglou, M. (2018). FLEXICURITY AND OBSTACLES IN FRONT: A STUDY FOR THE TOURISM SECTOR IN TURKEY. GeoJournal of Tourism and Geosites, 22(2), 497-508. https://doi.org/10.30892/gtg.22219-306
\end{abstract}

\begin{abstract}
The concept of flexicurity, which is a combination of flexibility and security words, involves the application of flexible working conditions providing security. There are various obstacles in the tourism sector of Turkey arising from the structural characteristics of the sector towards the applicability of the concept of flexicurity. In the study, the tourism sector was examined in terms of employment structure, working hours, wages, social protection, and representativeness, and evaluations were made on the dimensions of flexicurity. The statistics used in the study are compiled from TUIK (TURKSTAT), Eurostat and the Ministry of Labor and Social Security and evaluated as accommodation and catering sector data. This secondary analysis of existing data involves obtaining datasets from studies that have already been completed in national sources and the results in this study showed that the concept of flexicurity in the tourism sector can be maintained as unsecured due to the structure of the industry.
\end{abstract}

Keywords: Security, flexibility, tourism, working conditions

\section{INTRODUCTION}

Flexibility, which is a concept that stands out as the ability to adapt to changes and differences (Tatlıoğlu, 2012, p. 69), is now based on new phenomena in workers and employers relations with the influence of globalization. And one of these formations is the concept of flexicurity. Flexicurity is a concept created by combining the concepts of flexibility and security. It was first used in the "Flexicurity and Security Act" admitted in the Netherlands in 1999, and initially adopted in the Scandinavian countries as one of the basic concepts of the employment strategy (Kuzgun, 2012, p. 36). In the 2003 European Employment Guidelines, "providing the right balance between flexibility and security that will help support the competitiveness of firms, increase quality and productivity at work and facilitate the adaptation of firms and workers to economic change" target was emphasized (Council of the European Union, Council Decision of 22 July 2003 on guidelines for the employment policies of the Member States, Official Journal of the European Union, 2003). With the concept of flexicurity, it is primarily aimed at providing consensus between employers seeking flexibility and deregulation in the labor market and employees who want to protect their rights and work under security (Çakır, 2009, p. 80).

\footnotetext{
* Corresponding author
} 
Besides the effects of the tourism sector, which creates employment opportunities for more than 260 million people worldwide and employs 2.210.00o people in Turkey (Topçubaşı, 2018), in the economy on the financial dimension, one of the most important effects that it creates is the employment effect due to labor-intensive production (T.R. Prime Ministry Investment Support and Promotion Agency, 2010, p. 3). The tourism sector has structural features such as the seasonal characteristics of employment, unfamiliarity with unionization, the further abundance of the need for untrained and non-qualified workforce in job opportunities, being the average age of the employed population young, and informality. The tourism sector in Turkey can be seen in a flexible but unsecured framework by its structure. Therefore, in this sector, which has an important effect on employment, the existence of the concept of flexicurity is open to debate.

\section{ELEMENTS and DIMENSIONS of FLEXICURITY}

\section{Elements of Flexicurity}

Flexicurity has three elements in it. These are synchronisation, negotiation between the parties, and weak or disadvantaged groups within or outside the labor market. Synchronization involves performing practices on flexibility while at the same time ensuring security. According to this element, it is necessary for the employee working with one of the flexible working patterns that the arrangements for social security and job and employment security should have also been made. Negotiations between parties require compromise of the parties as the result of the evaluation of flexibility and security demands expectations from both the worker and the employer's sides. Flexicurity also serves as a protection for weak and disadvantaged groups in the labor market. The fact that flexible working is seen mostly in disadvantaged groups such as women and young people also causes income and job security to be for these groups (Çakır, 2009, p. 81-82).

\section{Dimensions of Flexicurity}

The concept of flexicurity has different dimensions in terms of security and flexibility.

Table 1. Dimensions of Flexicurity (Data source: *Çakır, 2009, 82; ${ }^{* *}$ Sağlanmak, 2010, 51)

\begin{tabular}{|l|l|}
\hline \multicolumn{1}{|c|}{ Dimensions of Flexibility* } & \multicolumn{1}{c|}{ Dimensions of Security** } \\
\hline & Labor Market Security \\
External Numerical Flexibility & Employment Security \\
Internal Numerical Flexibility & Job Security \\
Functional Flexibility & Occupational Safety Security \\
Wage Flexibility & Income Security \\
& Representation Security \\
\hline
\end{tabular}

The dimensions of flexibility are briefly explained as follows (Çakır, 2009, p. 82);

External Numerical Flexibility: It expresses the flexibility to adjust the number of employees.

Internal Numerical Flexibility: It defines flexibility of working times.

Functional Flexibility: The flexibility to work in more than one job.

Wage Flexibility: The flexibility of determining the wage according to performance and economic conditions.

The dimensions of security are explained as follows (Atatanır, 2012, p. 7-9);

Labor Market Security: Emphasis is placed on the level of being able to internalize a system that concentrates on active labor market policies and education in order to ensure that all those seeking to be employed have access to job opportunities.

Employment Security: Whether at the same or different workplaces, the emphasis is on securing the possibility of being employed rather than the job in ensuring the employment continuity. 
Job Security: It appears as normative regulations that take care of the right to work by protecting employees who provide their livelihood with their efforts against unfair terminations, and that aim to protect employees by limiting the termination process of the employer in case of termination of employment contracts for an unfair reason.

Occupational Safety Security: It is the total of systematic works that are carried out in order to ensure the security of the production/service process. While some flexible work patterns permit more free time for workers, the lengthiness of working time leads to excessive fatigue, distraction and lack of motivation in workers, so this can lead to a number of hazards in terms of the worker's health and safety.

Income Security: It can be expressed as the continuity of income suitable and consistent with the anticipated requirements, expectations and demands of the individual. Income is the most basic security for the working individual and for the survival of those he/she is obliged to look after. In this sense, it is essential that income is both sufficient and continuous.

Representation Security: Within the framework of practices such as union rights and collective bargaining, it expresses the right and need of the employee to be listened to.

\section{METHODOLOGY}

The purpose of this study was to unveil the applicability of the concept of flexicurity in the tourism industry in Turkey. This was examined in terms of employment structure, working hours, wages, social protection, representativeness and evaluations which were made on the dimensions of flexicurity. Current national and international statistical datasets were used as secondary data to show the structure of the tourism industry. Evaluations and comments were made according to the datasets.

\section{STRUCTURAL PROPERTIES OF TOURISM IN TURKEY AND RELATIONSHIP WITH FLEXICURITY}

Following the information on the concept of flexicurity, the obstacles to the concept of flexicurity due to the structural characteristics of the tourism sector in Turkey are addressed in this section. The tourism sector will be considered in five different titles: employment structure, working times, wages, social protection, and representativeness. Following the situation analysis in each title, the existing obstacles to flexicurity are interpreted.

\section{Employment Structure of Tourism Sector in Turkey}

Enterprises in the tourism sector are qualified enterprises. For this reason, tourism is a sector that is obliged to employ with the establishment of qualified workforce. The most important elements of the quality in tourism enterprises, where the service standard is required to be kept high, are the qualification and performance of the qualified employees. However, employment in tourism enterprises is seasonal. Due to this feature, employment can be unqualified especially in hospitality enterprises operated for holiday tourism. In addition to its seasonality feature, in a large part of the enterprises, cheap labor procurement and thus unqualified personnel recruitment are observed. Employment is either met with local resources or with trainees from educational institutions at all levels, except for senior and mid-level managers. This contrasts with functional flexibility which allows one to work in more than one job. As the result of the non-qualified nature of employment, one cannot work in different jobs. The characteristics of potential employment in the tourism sector can be summarized as follows (Taşçılar, 2008).

- Tourism enterprises employ a younger workforce than other sectors.

- Compared to the other sectors, the number of workers working in tourism enterprises is higher. 
- It is observed that the turnover rate of the personnel is high in the enterprises with the reason of the seasonality feature.

- The majority of workers are working in accommodation enterprises. This is in turn followed by travel and restaurant enterprises.

Considering Turkey from the demographic point of view, while the number of females, child and elderly personnel employed in the tourism sector due to the familyowned enterprise type is higher than other sectors, the overall tendency in the case of education is toward being semi-qualified and uneducated although the education level differs according to the regions and enterprise types in the sector. Due to its seasonality feature, employment in the tourism sector approaches full employment during periods of intense tourism demand (Lordoğlu, 2009, p. 68). According to a study conducted in 2012, the second largest sector of women's employment in Turkey among all sectors was the tourism sector including food and beverage services. The number of women working in this field of activity has reached 280,000 with an increase of 38,000 compared to the previous year (TEPAV, 2012, p. 21). Gender discrimination in employment is one of the most important issues of the United Nations. Poverty rates have also been observed to be low in countries where gender discrimination is low (Bolwell \& Weinz, 2008b, p. 6). However, education and skill levels, career opportunities, wages and working conditions of the female workforce working in the tourism sector as a whole are generally weak. Women are even paid 20\%-25\% less than their male colleagues who do the same job, are exposed to unequal discriminatory behavior, and experience stress, violence, and even sexual abuse (Bolwell \& Weinz, 2008 a, p. 11).

Table 2. Numbers of Female and Male Employment in Accommodation and Food-Service Activities in Turkey 2004-2017 (Thousand people) (Data source: TUIK, Labor Statistics, 2017)

\begin{tabular}{|c|c|c|c|c|}
\hline YEARS & PERIOD & TOTAL & MALE & FEMALE \\
\hline $\mathbf{2 0 0 4}$ & ANNUAL & 812 & 726 & 86 \\
\hline $\mathbf{2 0 0 5}$ & ANNUAL & 877 & 777 & 100 \\
\hline $\mathbf{2 0 0 6}$ & ANNUAL & 931 & 820 & 111 \\
\hline $\mathbf{2 0 0 7}$ & ANNUAL & 988 & 851 & 138 \\
\hline $\mathbf{2 0 0 8}$ & ANNUAL & 998 & 850 & 148 \\
\hline $\mathbf{2 0 0 9}$ & ANNUAL & 1049 & 889 & 161 \\
\hline $\mathbf{2 0 1 0}$ & ANNUAL & 1084 & 917 & 167 \\
\hline $\mathbf{2 0 1 1}$ & ANNUAL & 1141 & 936 & 204 \\
\hline $\mathbf{2 0 1 2}$ & ANNUAL & 1206 & 965 & 242 \\
\hline $\mathbf{2 0 1 3}$ & ANNUAL & 1308 & 1025 & 284 \\
\hline $\mathbf{2 0 1 4}$ & ANNUAL & 1351 & 1073 & 278 \\
\hline $\mathbf{2 0 1 5}$ & ANNUAL & 1449 & 1132 & 317 \\
\hline $\mathbf{2 0 1 6}$ & ANNUAL & 1471 & 1127 & 344 \\
\hline $\mathbf{2 0 1 7}$ & ANNUAL & 1523 & 1151 & 372 \\
\hline
\end{tabular}

The labor participation rate in Turkey was found as $52.8 \%$ according to the data of 2017. 33.6\% of the employment is made up of women. Men make up 73.5\% of employment (TUIK, Labor Statistics). According to the TUIK data, the number of people employed in the activity field of accommodation and catering services of the tourism sector has increased since 2004. The number of women employed in the tourism sector can be higher than that of other sectors as the employment opportunities based on women's knowledge and skills are higher (Bahar \& Kozak, 2006, p. 139), but the unequal superiority of the number of male employees is also remarkable. As can be seen from the table above, the number of 
part-time employees in the accommodation and food-beverage sector in Turkey is very low. It corresponds to about $0.5 \%$ of the total number of employees. Male workers are more involved in partial works than female workers. Since the number of male employees is also seen to be superior in the total number of employees.

Table 3. Accommodation and Food-Beverage Activity Branch Employees by Gender and Part-Time Working Status in Turkey (2013-2017) (Thousand people)

(Data source: EUROSTAT, Full-time and part-time employment by gender and economic activity, 2017)

\begin{tabular}{|c|c|c|c|c|c|c|c|c|c|c|}
\hline & \multicolumn{2}{|c|}{2013} & \multicolumn{2}{|c|}{2014} & \multicolumn{2}{|c|}{2015} & \multicolumn{2}{|c|}{2016} & \multicolumn{2}{|c|}{2017} \\
\hline & $\mathbf{F}$ & $\mathbf{M}$ & $\mathbf{F}$ & $\mathbf{M}$ & $\mathbf{F}$ & $\mathbf{M}$ & $\mathbf{F}$ & M & $\mathrm{F}$ & M \\
\hline $\begin{array}{c}\text { All } \\
\text { Employees }\end{array}$ & 284 & 1.025 & 278 & 1.073 & 317 & 1.132 & 344 & 1.127 & 372 & 1.151 \\
\hline Total & \multicolumn{2}{|c|}{1.308} & \multicolumn{2}{|c|}{1.351} & \multicolumn{2}{|c|}{1.449} & \multicolumn{2}{|c|}{1.471} & \multicolumn{2}{|c|}{1.523} \\
\hline $\begin{array}{l}\text { Part- Time } \\
\text { Employees }\end{array}$ & 23 & 41 & 28 & 44 & 31 & 48 & 33 & 48 & 32 & 55 \\
\hline Total & \multicolumn{2}{|c|}{64} & \multicolumn{2}{|c|}{72} & \multicolumn{2}{|c|}{79} & \multicolumn{2}{|c|}{81} & \multicolumn{2}{|c|}{87} \\
\hline
\end{tabular}

The rate of informal employment in the tourism sector was 40\% by 2012 (Sönmez, 2012). While the informal employment rate in Turkey was $37.9 \%$ in 2012, it is known that agricultural workers constitute this rate to a large extent. When we take out agricultural workers from this rate, the resultant rate becomes $24.2 \%$, which is considerably lower than the rate of informal workers in accommodation and food-beverage activity field (TEPAV, 2013, p. 13). Therefore, informal work in the sector is quite common.

Considering the employment structure of the tourism sector in terms of flexicurity, it can be said that the sector is open to external numerical flexibility. Because of the fact that the tourism sector has seasonal feature and is made up of small enterprises, it has caused environmental employment to come to the fore alongside core employment. Thus, when the job is available, some labor is employed, and when the job is done, the ones who are not within the core employment are left unemployed until a new job comes out (Saraçoğlu \& Suiçmez, 2008). On-call working, part-time working and seasonal working support the external numerical flexibility, that is the flexibility to adjust the number of employees in the tourism sector. On the other hand, while external numerical flexibility is supported, despite the existence of the Equal Treatment Principle (TBMM, Labor Law No. 4857) in Article 5 of the Labor Law No. 4857, which stipulates that workers do not suffer any discrimination on security during they chose their work and while they work, the numbers obtained from the tables show the existence of a negative situation regarding the job market and employment security both in full-time work and in parttime work. The number of people who work part-time as registered is quite low. In addition, when the security is applied only to formal employees, with an informal rate of $40 \%$, the tourism sector constitutes a major obstacle to all dimensions of security.

\section{Working Times in the Tourism Sector in Turkey}

The tourism sector exhibits an atypical character in terms of working times (Bolwell \& Weinz, 2008a, p. 2). In the tourism sector, "over 16 hours daily work" has become widely accepted and widely applied as working times. At the same time, seasonal and shift working conditions cause the emergence of a working model that is more different than other sectors (T.R. Ministry of Labor and Social Security, Labor Inspection Board, 2013). Especially in the hotels and restaurants, the working times are quite irregular. Because of the 24-hour service, shift work is common. Weekend shifts, night shifts, and shift work even at the holidays are seen. Employees can work on-call, temporarily, seasonally or parttime. This situation leads to more unsecured, less paid, unstable, more limited career opportunities and thus a faster turnover rate (ILO, 2010, p. 14). 
Another negative effect of irregular working hours is on the employees' families and social lives. People can spend less time with their families and in their social lives. This can lead to an imbalance between work and social life (Beddoe, 2004, p. 16). The positive effect of irregular working times is to allow people to work flexibly. Thus, employees can themselves determine when they spare time to their families and social lives. However, this has become valid especially in developed countries and in situations where part-time working is voluntary (ILO, 2010, p. 15). In order for irregular working times to have a positive effect on the tourism sector, the flexibility of these working times should be specified by the employees themselves. In a workplace that supports flexible or part-time working hours, an employee who specifies these times himself/herself may be more productive (Deery \& Jago, 2009, p. 104).

Table 4. Weekly Normal Working Time in Turkey (Data source: TUIK, Labor Statistics, 2014)

\begin{tabular}{|l|c|c|c|c|}
\hline & & $\mathbf{2 0 0 6}$ & $\mathbf{2 0 1 0}$ & $\mathbf{2 0 1 4}$ \\
\hline \multirow{3}{*}{ All sectors weekly normal working time } & Female & 44.7 & 44.5 & 44.6 \\
\cline { 2 - 5 } & Male & 44.9 & 44.7 & 44.8 \\
\cline { 2 - 5 } & Mean & 44.9 & 44.7 & 44.7 \\
\hline \multirow{2}{*}{$\begin{array}{l}\text { Accommodation and Food-Beverage, } \\
\text { weekly normal working time }\end{array}$} & Female & 45 & 45,1 & 44.9 \\
\cline { 2 - 5 } & Male & 45,1 & 45.2 & 44.9 \\
\cline { 2 - 5 } & Mean & 45,1 & 45,1 & 44.9 \\
\hline
\end{tabular}

In Turkey, the weekly working time is 45 hours maximum (Evren, 2012, p. 107). In view of the above table, it is observed that the rule of working 45 hours per week found in the Labor Law in Turkey is agreed with the mean of all sectors. However, in works on accommodation and food-beverage field, it is also found that this time was slightly exceeded in 2006 and 2010. Although the time exceeding 45 hours is very small, it forms a negative situation. This is less than 45 hours in 2014 data and it appears to be in line with the law. The internal numerical flexibility dimension of flexicurity is defined as the flexibility in working times. As is seen, the tourism sector is a sector where various flexibilities such as shift work, part-time work, night work, seasonal work can easily be applied due to uninterrupted service. However, regarding the security, the lengthiness of working hours in terms of occupational safety security gets the worker to encounter dangers of distraction and deterioration of health. Besides, flexible working hours are determined by employer in the tourism sector rather than worker. Besides these, the lengthiness of working hours and works exceeding 45 hours in the tourism sector can be considered as negative in terms of flexicurity.

\section{Wages in the Tourism Sector in Turkey}

In the tourism sector, there is a problem about wages globally. This is because wages are lower than other sectors. The reason for this low rate is that there are additional payments under the name of service fee and tip, especially in hotels and restaurants. The fixed wages of the employees are at the minimum wage levels, and wages can be increased thanks to these additional payments.

Unpaid additional payments cause employees to experience difficulties. If the demand for tourism and the income from tourism are on the rise in the country, this situation will manifest itself with the increase in the additional payments, but in the dead seasons of tourism or when the tourism demand decreases due to external factors (economic crisis, war etc.), the economic difficulties for employees will arise due to the decrease in these payments (Beddoe, 2004). Especially the "all-inclusive" pension system, which has increased in recent years in accommodation enterprises, is seen as one of the important factors for decreasing the additional wages of workers (Tütüncü \& 
Demir, 2003, p. 150). In pricing at the hotel enterprises, there are internal environment and labor costs such as performance-based pricing that managers can control, various factors related to the external environment which can be summarized as laws, trade unions, social security, technological developments, competitors and market conditions, economic and social conditions (İzgi \& Olcay, 2008, p. 46).

Table 5. Mean and Median Monthly Gross Wages in Turkey According to Gender and Economic Activity of Full Year Employees (TL) (Data source: TUIK, Labor Statistics, 2014)

\begin{tabular}{|c|l|c|c|c|c|}
\hline \multicolumn{2}{|c|}{} & \multicolumn{2}{c|}{$\begin{array}{c}\text { All sectors monthly } \\
\text { gross wage }\end{array}$} & $\begin{array}{c}\text { Accommodation \& Food- } \\
\text { Beverage monthly gross wage }\end{array}$ \\
\cline { 3 - 6 } \multicolumn{2}{|c|}{} & Mean & Median & Mean & Median \\
\hline \multirow{3}{*}{2006} & Female & 1280 & 658 & 991 & 583 \\
\cline { 2 - 6 } & Male & 1277 & 701 & 843 & 550 \\
\cline { 2 - 6 } & Turkey & 1278 & 698 & 873 & 550 \\
\hline \multirow{3}{*}{$\mathbf{2 0 1 0}$} & Female & 1844 & 1019 & 1266 & 883 \\
\cline { 2 - 6 } & Male & 1758 & 1025 & 1334 & 907 \\
\cline { 2 - 6 } & Turkey & 1779 & 1025 & 1322 & 906 \\
\hline \multirow{3}{*}{2014} & Female & 2711 & 1517 & 1741 & 1243 \\
\cline { 2 - 6 } & Male & 2617 & 1600 & 1842 & 1398 \\
\cline { 2 - 6 } & Turkey & 2642 & 1582 & 1824 & 1378 \\
\hline
\end{tabular}

Considering the above mean and median wages table, the difference between the mean and the median wage draws attention both to the whole of all sectors and to the accommodation and food-beverage field. Although the mean wages are higher both in women, in men, and in general, the median wages are quite low. This shows the wage imbalance, that is, while a large part of the employees work at low wages, a small part work at high wages. It is observed that the wages are lower in the tourism sector compared to Turkey in general.

Table 6. Labor Costs, 2016 (Data source: TUIK, Labor Statistics, 2016)

\begin{tabular}{|c|c|c|c|c|}
\hline Labor Cost & $\begin{array}{c}\text { Monthly mean } \\
\text { labor cost (TL) }\end{array}$ & $\begin{array}{c}\text { Gross Profit } \\
\text { (\%) }\end{array}$ & $\begin{array}{c}\text { Social security } \\
\text { payments (\%) }\end{array}$ & $\begin{array}{c}\text { Other labor cost } \\
\text { payments (\%) }\end{array}$ \\
\hline Turkey's Average & 3991 & 82.9 & 16.7 & 0.4 \\
\hline Hotels and estaurants & 3003 & 82.3 & 17.35 & 0.3 \\
\hline
\end{tabular}

Regarding the flexicurity perspective, it can be said that the income security dimension is not met in the tourism sector as a result of wage imbalance. Because wage flexibility has a nature that is influenced by other flexibility practices or supports them. By this way, as highly skilled workers can be rewarded, being able to reduce wages can provide competitive advantage to the firm in times of economic crisis and bottlenecks. By this, it is also impressed by the worker the thought that job security is provided in exchange for reducing the wage. It is expressed that wage costs constitute one of the most important elements of wage flexibility economic strategies in terms of enterprises. Wage costs are considered as directly related to the profitability and competitiveness of enterprises or business fields. The wage flexibility practice has a role in reducing costs (Eryiğit, 2009, p. 11). According to the above Table 6, in the accommodation and foodbeverage field, which is one of the activity fields of the tourism sector with the greatest employment and economic contribution, labor costs are located below the mean in Turkey. Total labor cost is 3991 TL in the average of all the activity fields in Turkey in 2016, while this figure is $3003 \mathrm{TL}$ in the accommodation and food beverage activity field. 
Therefore, employers should not be allowed to turn towards wage flexibility to reduce costs, because costs are already low. In addition, the tourism sector is a sector with low wages in global context. This situation can easily be seen in Table 5 . The wages of both men and women are much lower than the Turkey wage mean for the sector as a whole. It can be argued that the income security has not been met in the tourism sector as per its structure, considering that the all-inclusive pension system, especially in seasonal enterprises, does not increase the wages, and that employment and therefore the wages are not continuous due to the seasonal employment.

\section{Social Protection in the Tourism Sector in Turkey}

Social protection, which is a very broad concept, is the protection of employees against various risks in the broadest sense. These risks are health, illness, unemployment, old age, occupational accidents and diseases, family benefits, maternity, invalidity and death risks included in the ILO Convention No. 102, which Turkey regards as many other countries in the world. "One of the most important problem fields that lead to insufficient social protection in the field of occupational health and safety is that occupational health and safety legislation encompass specific sectors or specific groups of employees, but they do not provide social protection for the rest of the employees" (Karadeniz, 2012, p. 29). In this regard, in Turkey, the new Occupational Health and Safety Law No. 6331 extends its coverage and ensures all workplaces and employees in all workplaces (including apprentices and trainees) to benefit from the occupational health and safety legislation (Akpınar, 2013, p. 256). However, only the insured ones have the right to receive the incapacity benefit for all risks. Therefore, many people who work informally cannot benefit from these rights. Especially small and medium-sized enterprises operating in the tourism sector in Turkey employ family labor or low-qualified migrant workers. Immigrants, who temporarily go to work in the regions where tourism enterprises are located, often work in such enterprises. These seasonal workers are employed informally. On the other hand, workers in large enterprises (especially those affiliated with international companies) form a more skilled workforce and are able to receive higher wages, and also work formally (Ayan, 2013). In tourism-related areas, the rate of informality has decreased in recent years. While the number of insured employees increased by $6.5 \%$ in Turkey, this ratio increased by $17 \%$ in the tourism sector in 2012 . For the reason, the increase in the number of companies included in SSI scope is mentioned (AKTOB, 2013, p. 19).

Table 7. Number of Insured Persons in the Field of Accommodation and Food-Beverage Services in Turkey, 2016 (Data source: Republic Of Turkey Social Security Institution, Annual Statistics, 2016)

\begin{tabular}{|c|c|c|c|c|c|c|c|}
\hline \multirow{2}{*}{$\begin{array}{c}\text { Tourism } \\
\text { Sector } 2016\end{array}$} & \multicolumn{7}{|c|}{ NUMBER OF COMPULSORY INSURED PERSONS } \\
\hline & \begin{tabular}{|c} 
Permanent \\
(I)
\end{tabular} & \begin{tabular}{|c|} 
Seasonal \\
(II)
\end{tabular} & \begin{tabular}{|c|} 
Public \\
(I)
\end{tabular} & \begin{tabular}{|c|} 
Private \\
(II)
\end{tabular} & Male (I) & $\begin{array}{l}\text { Female } \\
\text { (II) }\end{array}$ & $\begin{array}{l}\text { Total } \\
(\mathrm{I}+\mathrm{II})\end{array}$ \\
\hline Accommodation & 189,215 & 2,961 & 3,885 & 188,291 & & 62,422 & 192,176 \\
\hline $\begin{array}{c}\text { Food and } \\
\text { beverage serv. }\end{array}$ & 530,978 & & 15,251 & 594,067 & 422,481 & 186,837 & 609,318 \\
\hline Total & & & & 782,358 & & & 801,494 \\
\hline $\begin{array}{c}\text { All sectors } \\
\text { together* }\end{array}$ & $10,810,326$ & $2,964,862$ & $\mathbf{1 , 0 5 9 , 3 3 3}$ & $12,715,855$ & $9,949,9$ & & $13,775,188$ \\
\hline
\end{tabular}

In order to have social protection, workers in Turkey must also be insured. In 2016, a total of 801,494 people work as compulsory insured in the accommodation and foodbeverage services activity field of the tourism sector in Turkey. According to TUIK data, $1,127,000$ men and 344,000 women work in accommodation and food-beverage services activities in Turkey in 2016 (TUIK, 2017). Looking at the insured numbers in the Table 7 
above, it is seen that the insurance ratio is $49 \%$ for males and $72 \%$ for females. It can be said that the social protection does not show a positive scene in the tourism sector in Turkey in terms of the concept of flexicurity. Particularly in terms of job security, the condition for employees to be secured in unfair job terminations is to work formally, as insured. Pursuant to Article 19 of the Labor Law No. 4857, the notice of termination shall be made in writing and the employment contract of an indefinite duration of an employee shall not be able to be terminated for reasons related to the behavior or the yield of that worker without taking his/her statement against the allegations about him (Evren, 2012, p. 73).

According to the Article 32 of the Labor Law, the termination of the employment contract requires payment of the employee's wages and all the benefits that may arise from the law and the contracts and that can be measured by money (Evren, 2012, p. 93). Apart from this, no discriminatory practice with regard to people working part-time can be performed. As clearly stated in the Article 13 of the Labor Law No. 4857, a worker who works with a part-time employment contract is not subject to a different process according to the worker who works under a full-time employment contract only because of the partial duration of the employment contract unless there is a justifiable reason to discriminate. As a matter of fact, the Labor Law has called for "having worked for at least one year", and has not made any evaluations in this regard relating to weekly or daily working time (Topçu, 2011, p. 230). In the light of the above data, it is observed that employees have been working in unsecured conditions on job security although legal practices exhibit a positive nature in terms of job security in the tourism sector where informality is so high, and the insured rate is $49 \%$ in males and $72 \%$ in females.

\section{Representation Security in the Tourism Sector in Turkey}

Employees in the tourism sector tend to be less organized compared to other sectors. Since the enterprises in the sector are mostly of small scale, the unionization rate in the industry is as low as $10 \%$ in the global framework. Although employees in certain hotels in major cities are frequently organized, the organization of employees in small hotels or in hotels serving out-of-town centers is weaker (Boz, 2006, p. 78). At the same time, the fact that workers in the sector are young and inexperienced can also cause them to abstain from union activities. In addition, employers in the sector do not think positively about unionisation, for seasonal and atypical working in the tourism sector is also quite common (ILO, 2013). The Ministry of Labor and Social Security in Turkey has collected trade unions under a total of 20 business lines in accordance with the Trade Unions and Collective Bargaining Agreements (Act No. 6356. The business line related to tourism from these business lines is the business line numbered 18 which is the Accommodation and Entertainment Businesses. According to the table below, there are 11 trade unions under this business line related to the tourism sector. Despite the high number of employment, the rate of unionization in the sector is very low. As of January 2018, the unionized rate is shown as $4.04 \%$. The general unionization rate for all employees in Turkey is 12.38\% (MoLSS, Number of Workers and Trade Union Members, 2018).

In Turkey, unionization in the tourism sector is about 4\%. Seymen and Kılıç have pointed out various factors in the declaration in a symposium for the reasons of the unionisation being not very effective. These factors can be summarized altogether as follows (Kılıç \& Seymen, 2011, p. 167-171).

- Structure of labor (young people, immigrants ...)

- Globalization and technology (predisposition to mechanization)

- Company and group mergers (companies employing within themselves)

- Subcontracting

- Economic and political instability

- Privatization 
- Excessive informal and seasonal employment rates

- Human resources policies are individual oriented rather than collective bargaining agreements

- Personnel turnover rate is high.

Table 8. Accommodation and Entertainment Businesses Unionisation Rates (as of January 2018) (Data source: The Ministry of Labor and Social Security, Statistics, 2018)

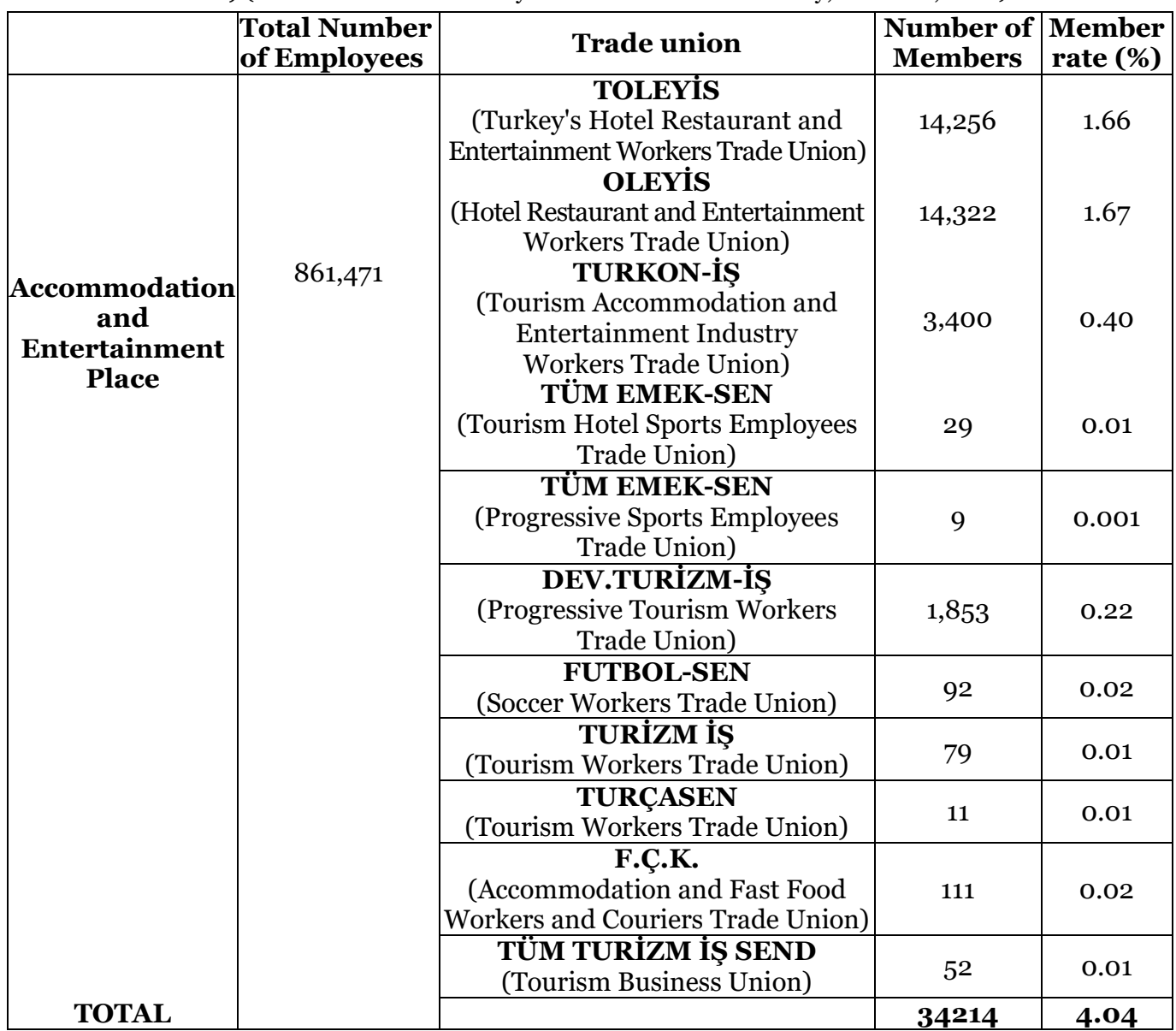

From the perspective of flexicurity, it is observed that the representation security is highly unfavorable in the tourism sector in Turkey when it is directly related to the unionization rate in the sector. The unionisation rate in the sector is about $4 \%$. And this is seen as the biggest obstacle in front of representation security.

\section{CONCLUSION}

The concept of flexicurity, first introduced in 1999, encourages the flexible working conditions of employees and employers to be secured and underlines the need for a compromise between the employee and the employer. Flexicurity incorporates various elements and dimensions. It includes the simultaneous application of flexibility and security by workers and employers, compromise between the parties, and to protect disadvantaged groups in their employment. 
The tourism sector, which is one of the most important branches of the services sector and totally dependent on human labor, has been examined within the five characteristics of the sector on flexicurity. The tourism sector, which is observed to not give women more right in terms of female employment in the statistics, shows a negative scene as the job market and the employment security with a high rate of informal workings. However, it is possible to say that the dimension of external numerical flexibility can be realized in the tourism sector thanks to the seasonality feature that allows the number of employees to be adjusted and kept flexible. In addition to this, the uneducated and low quality structure of employment creates an environment opposite the functional flexibility that allows the worker to do more than one job. While it can be said that the tourism sector in Turkey constitutes an obstacle to the concept of flexicurity in terms of income and occupational safety security with the working times over 45 hours determined by the labor law, the internal numerical flexibility is implemented to the sector in terms of flexibility of working times such as part-time working, on-call working and seasonal working. However, this flexibility is not determined by the worker, but he/she works within flexible hours determined by the employer. The fact that the wages are low in the sector as a whole and the labor cost is below the mean in Turkey are obstacles to the implementation of the wage flexibility.

In addition, the low ratio of insured workers and the very low unionisation rate compared throughout Turkey underlines the obstacles to sector's flexicurity practices on job security and representation security. As a result, the concept of flexicurity in the tourism sector can be maintained as unsecured due to the structure of the industry. None of the dimensions of security is met, and only extrinsic numerical elasticity and intrinsic numerical elasticity dimensions of the flexibility are met.

\section{REFERENCES}

Akpınar, T. (2013). Occupational Health and Job Safety (İş Sağlı̆̆ı ve İş Güvenliği), Bursa: Ekin Basım Yayın.

Atatanır, H. (2012). Is "Social” Flexicurity Possible in Turkey? (Türkiye'de "sosyal" güvenceli esneklik mümkün mü?). Sosyal Güvence Dergisi, 2, 5-27.

Ayan, E. (2013). Tourism's relation to other sectors and contribution on employment (Turizmin diğer sektörlerle ilişkisi ve istihdama katkısı), (Çevrimiç) http://markakent.com/kose-yazisi/turizmin-diger-sektorlerleiliskisi-ve-istihdama-katkisi- 24.09.2013.

Bahar, O., \& Kozak, M. (2006). Tourism Economics (Turizm Ekonomisi). Ankara: Detay Yayıncılık.

Beddoe, C. (2004). Labour standarts, social responsibility and tourism. A Report by Tourism Concern.

Bolwell, D., \& Weinz, W. (2008) a. Guide for social dialogue in the tourism industry. ILO Sectoral Activities Programme.

Bolwell, D., \& Weinz, W. (2008) b. Reducing poverty through tourism, ILO Sectoral Activities Programme.

Boz, C. (2006). The employment and the woking conditions in tourism industry in the world (Dünyada turizm endüstrisinde istihdam ve çalışma şartları). Yayımlanmamış Yüksek Lisans Tezi, Marmara Üniversitesi Sosyal Bilimler Enstitüsü, İstanbul.

Çakır, Ö. (2009). Flexicurity and trends in European Union (Avrupa Birliği'nde güvenceli esneklik ve eğilimler). Sosyoekonomi, 2, 77-94.

Deery, M., \& Jago, L. (2009). A framework for work - life balance practices: addressing the needs of the tourism industry. Tourism and Hospitality Research, 9, 97-108.

Eryiğit, S. (2009). Flexible production, flexible organization, flexible work (Esnek Üretim, Esnek Organizasyon Esnek Çalıșma), Kamu-İş, (Çevrimiçi), http://www.kamu-is.org.tr/pdf/5411.pdf,s.11, 23.09.2014.

Evren, Ö. K. (2012). The handbook of the employer in terms of work law. (İş Mevzuatı Açısindan İşverenin El Kitabı.) Ankara: Seçkin Yayıncılık.

İzgi, B.B., \& Olcay, A. (2008). Importance of working conditions: an operational research about 4 and 5 star hotels in the city of Gaziantep (Çalışma koşullarının önemi: Gaziantep ilindeki 4 ve 5 yldızlı otel işletmesi çalışanlarına yönelik bir araştırma). Gazi Üniversitesi İktisadi ve İdari Bilimler Fakültesi Dergisi, 10(1), 43-62.

Karadeniz, O. (2012). Work accidents and occupational diseases in the World and in Turkey and the insufficiency of socil protection (Dünya'da ve Türkiye'de iş kazaları ve meslek hastalıkları ve sosyal koruma yetersizliği). Çalışma ve Toplum, 3, 15-75. 
Kılıç, T., \& Seymen, O.A. (2011). Why is trade union organization not strong in Turkish tourism sector? A literary assessment of the role and effects of dominant factors (Türk turizm sektöründe sendikal örgütlenme neden güçlü değil? Baskın faktörlerin rolü ve etkileri üzerine yazınsal bir değerlendirme). II. Turizmde İnsan Kaynakları Sempozyumu, Antalya.

Kuzgun, İ.K. (2012). Concept of flexicurity and determining indicators of flexicurity in Turkey (Güvenceli esneklik kavramı ve Türkiye'de güvenceli esnekliğin belirleyici değişkenleri). Sosyal Güvenlik Dergisi, 2, 35-48.

Lordoğlu, K. (2009). New problems that occur in the labor market and immigrant workers in tourism in Turkey (Türkiye'de turizmde çalışan göçmenler ve işgücü piyasasında oluşan yeni sorunlar). II. Uluslararası Eğitim ve Uyum Bağlamında Avrupalı Türkler Kongresi, Belçika.

Sağlanmak, H. (2010). The concept of flexicurity and its place in Turkish work life (Güvenceli esneklik kavramı ve Türk çalışma hayatındaki yeri). Yayınlanmış Yüksek Lisans Tezi, İstanbul Üniversitesi, İstanbul.

Saraçoğlu, B., \& Suiçmez, H. (2008). Growth, Employment and Productivity Problems in Turkish Manufacturing Industry. (Türkiye İmalat Sanayinde Büyüme, İstihdam ve Verimlilik Sorunları). TíSK Akademi, 2008/II, Cilt:3 Sayı:6(88).

Sönmez, M. (2012). The unregistred employment in Turkey is \%40. (Türkiye'de kayıt dışı istihdam \%40!). (Çevrimiçi), http://www.turizmhabercisi.com/turizmde-kayit-disi-istihdam-yuzde-40.html, 13.05.2014.

Taşçlar, N. (2008). Creating employment in Tourism (real income) (Turizmde istihdam yaratılması (Reel Gelir). Tourism \& Hotel Management, (Çevrimiçi), www.xing.com.

Tatlığlu, E. (2012). The applicability of flexible working within the framework of flexicurity (Güvenceli esneklik çerçevesinde esnek çalışmanın uygulanabilirliği). Electronic Journal of Vocational Colleges, Aralık, 69-84.

Topçu, U. (2011). Annual paid leave rights of part ime contracted employees. (Kısmi süreli iş sözleşmesiyle çalışanların yıllık ücretli izin hakkı). Mali Çözüm, Eylül-Ekim.

Topçubaşı, A. (2018). The importance of tourism in terms of employment. (Turizmin istihdam açısından önemi). Turizm Gazetesi. (Çevrimiçi) http://www.turizmgazetesi.com/article.aspx?id=85118.

Tütüncü, Ö., \& Demir, M. (2003). The analysis of labour turnover rate at hospitality businesses in the concept of human resources and the case of Mugla region. (Konaklama işletmelerinde insan kaynakları kapsamında işgücü devir hızının analizi ve Muğla bölgesi örneği). Dokuz Eylül Üniversitesi Sosyal Bilimler Enstitüsü Dergisi, 5(2).

*** AKTOB Araştırma Birimi. (2013). Tourism Report (Turizm raporu), TÜROFED, 2(6).

*** Council of the European Union (2003). Council Decision of 22 July 2003 on guidelines for the employment policies of the Member States, Official Journal of the European Union.

*** ILO. (2010). Developments and challenges in the hospitality and tourism sector. Issues Paper for Discussion at the Global Dialogue Forum for the Hotels, Catering, Tourism Sector.

*** ILO. (2013). Hotel, catering and tourism sector. Sectoral Brief, (Çevrimiçi), http://www.ilo.org/global/industries-and-sectors/hotels-catering-tourism/lang--en/index.htm, 17.12.2013.

*** Labour Law in Turkey, Article 5, Pronciple of equal treatment. (4857 Sayılı İş Kanunu, 5. Madde, Eşit Davranma İlkesi), (Çevrimiçi), https://www.ilo.org/dyn/natlex/docs/ELECTRONIC/64083/77276 /\%20F75317864/TUR64083\%20English.pdf.

*** TEPAV. (2012). Employment monitoring bulletin (İstihdam İzleme Bülteni), 7.

*** TEPAV. (2013). Employment monitoring bulletin (İstihdam İzleme Bülteni), 23.

*** T.R. Act No. 6356 on Trade Unions and Collective Labour Agreements. (Online) http://www.ilo.org/ dyn/natlex/docs/MONOGRAPH/91814/106961/F2018685492/TUR91814\%20Eng.pdf.

*** T.R. Prime Ministry Investment Support and Promotion Agency. (2010). Türkiye turizm sektörü raporu, (Çevrimiçi), http://www.miceplatform.com/images/doc/turizm-sektoru.pdf, 20.03.2013.

*** T.R. The Ministry of Labor and Social SecuritY. (2018). İşçi ve Sendika Üye Sayıları. (Çevrimiçi) https://www.csgb.gov.tr/home/contents/istatistikler/iscisendikauyesayilari/ 30.04.2018.

*** T.R. The Ministry of Labor and Social Security. (2011). Turizm sektöründe çalışma sürelerinin iyileştirilmesi programl teftişi sonuç raporu, (Çevrimiçi), http://www.csgb.gov.tr/csgbPortal/ShowProperty/ WLP\%20Repository/itkb/dosyalar/yayinlar/yayinlar2013/2011_48, 15.07.2014.

*** TÜİK. (Turkish Statistical İnstitute - TURKSAT). (2017). Labour Statistics (İsgücü İstatistikleri) (Çevrimiçi) http://www.tuik.gov.tr/PdfGetir.do?id=24633.

Submitted:

02.04.2018
Revised:

29.06.2018
Accepted and published online 02.07.2018 